\title{
Enthalpy of sublimation/vaporization of trans-cyclohexyl-1,4-diamine and cis-cyclohexyl-1,2-diamine
}

\author{
Luciana I.N. Tomé ${ }^{\text {a }}$, Mário T.S. Rosado ${ }^{a}$, Sandra C.C. Nunes ${ }^{\text {a }}$, Teresa M.R. Maria ${ }^{\text {a }}$, \\ João Canotilho ${ }^{\mathrm{b}}$, M. Ermelinda S. Eusébio ${ }^{\mathrm{a}, *}$ \\ a Department of Chemistry, Rua Larga 3004-535, University of Coimbra, Portugal \\ ${ }^{\mathrm{b}}$ Faculty of Pharmacy, Rua do Norte 3000-295, University of Coimbra, Portugal
}

Received 7 May 2007; received in revised form 12 June 2007; accepted 24 June 2007

Available online 5 July 2007

Dedicated to Professor J. Simões Redinha on the occasion of his 80th birthday

\begin{abstract}
The molar enthalpy of sublimation, $\Delta_{\mathrm{cr}}^{\mathrm{g}} H_{\mathrm{m}}^{\circ}$, of trans-cyclohexyl-1,4-diamine and the molar enthalpy of vaporization, $\Delta_{1}^{\mathrm{g}} H_{\mathrm{m}}^{\circ}$, of $c i s-$ cyclohexyl-1,2-diamine, at the temperature $298.15 \mathrm{~K}$, were determined by calorimetry. $\Delta_{\mathrm{cr}}^{\mathrm{g}} H_{\mathrm{m}}^{\circ}(T=298.15 \mathrm{~K})=(105.0 \pm 0.8) \mathrm{kJ} \cdot \mathrm{mol}{ }^{-1}$ was obtained for the trans-isomer and $\Delta_{\mathrm{l}}^{\mathrm{g}} H_{\mathrm{m}}^{\circ}(T=298.15 \mathrm{~K})=(62.2 \pm 1.0) \mathrm{kJ} \cdot \mathrm{mol}^{-1}$ for the cis form. The molar enthalpy of fusion of the first compound, at $T=342.1 \mathrm{~K}$, was determined by differential scanning calorimetry. The molar enthalpy of vaporization of the 1,4-isomer was estimated by combining the value of the enthalpy of sublimation with that of the enthalpy of fusion.

The values obtained for molar standard enthalpy of vaporization and those available for the enthalpy of the diamines in the gas state were used to calculate the difference between the enthalpies of both compounds in the liquid state.
\end{abstract}

(C) 2007 Elsevier Ltd. All rights reserved.

Keywords: trans-Cyclohexyl-1,4-diamine; cis-Cyclohexyl-1,2-diamine; Sublimation/vaporization; Cyclohexyldiamines

\section{Introduction}

Numerous compounds occurring in nature, prepared in the laboratory as reagents or by chemical and pharmaceutical industries contain amine groups that play an important role in their chemical behaviour [1-7]. Despite their importance, some basic aspects related to the structure of amine compounds are still waiting to be clarified.

Since the gas state is commonly used as the standard reference state of thermodynamic properties, the enthalpy of sublimation/vaporization is a very useful quantity. It is, for instance, the term needed in important thermodynamic cycles to calculate the enthalpy of solvation from the data obtained experimentally for solution and sublimation/ vaporization.

\footnotetext{
${ }^{*}$ Corresponding author. Tel.: +351 239854450; fax: +351 239827703.

E-mail address: quierme@ci.uc.pt (M. Ermelinda S. Eusébio).
}

Furthermore, the enthalpy of sublimation/vaporization allows the calculation of the enthalpy in the solid or liquid states, provided the enthalpy of the compounds in the gas state is known. In previous work, the authors calculated the enthalpy of the amines under study in the gas phase $[8,9]$. The enthalpy of the diamines under study in the liquid state can therefore be estimated from the enthalpy of vaporization and the enthalpy in the gas state.

\section{Experimental}

The cyclohexyldiamines studied were purchased from Fluka, with the specified purity corresponding to a mass fraction $x \geqslant 0.99$ for trans-cyclohexyl-1,4-diamine and $x \geqslant 0.98$ for the cis-1,2-isomer. Purity was checked by gas chromatography-mass spectrometry using an HP Agilent 6890 chromatograph with an SGE HP-5MS column, and an HP 5973 MSD mass spectrometer, with an electron 
impact source. No impurities were detected in the trans-isomer and $x=0.99$ was found for purity for cis-cyclohexyl1,2-diamine. The absence of water was checked by infrared spectroscopy using a Mattson infrared spectrometer and by differential scanning calorimetry using a Perkin-Elmer Pyris 1 calorimeter. The substances under study were used without any further purification, kept in a dry atmosphere and handled in a glove box filled with dry nitrogen.

The enthalpy of sublimation/vaporization was determined by calorimetry with a Knudsen effusion cell, using the procedure described elsewhere [10]. Measurements were taken at $T=298.15 \mathrm{~K}$. Effusion holes with diameter $\phi_{0}=0.1 \mathrm{~mm}$ and $\phi_{0}=0.05 \mathrm{~mm}$ were used for trans-cyclohexyl-1,4-diamine and cis-cyclohexyl-1,2-diamine, respectively, and the experiments were carried out under conditions leading to the total vaporization of the substance in the cell. The effusion rate was of the order of $v=3 \cdot 10^{-10} \mathrm{~kg} \cdot \mathrm{s}^{-1}$ in the case of the trans-1,4-isomer and $v=1 \cdot 10^{-9} \mathrm{~kg} \cdot \mathrm{s}^{-1}$ for the other compound studied. For both compounds the enthalpies of phase transition determined experimentally can be equated to the standard state quantity.

The temperature and the enthalpy of fusion of transcyclohexyl-1,4-diamine, which is a solid at $T=298.15 \mathrm{~K}$, were determined by differential scanning calorimetry, with a Perkin-Elmer Pyris 1 calorimeter, following the procedure described elsewhere [11].

In this work, uncertainties are expressed as one standard deviation units.

\section{Results}

The results obtained for the enthalpy of sublimation/ vaporization for different masses of trans-1,4- and ciscyclohexyl-1,2-diamine at $T=298.15 \mathrm{~K}$, as well as their mean value and standard deviation, are presented in tables 1 and 2 , respectively.

As trans-cyclohexyl-1,4-diamine is solid and cis-cyclohexyl-1,2-diamine is liquid at room temperature, to compare the structure of the two compounds in the same state of matter we have to calculate the standard enthalpy of vaporization at $T=298.15 \mathrm{~K}$, for the first compound.
TABLE 2

Enthalpy of vaporization values, $\Delta_{1}^{\mathrm{g}} H_{\mathrm{m}}$, at $T=298.15 \mathrm{~K}$ obtained for different masses, $m$, of $c i s$-cyclohexyl-1,2-diamine

\begin{tabular}{rl}
\hline$m / \mathrm{mg}$ & $\Delta_{1}^{\mathrm{g}} H_{\mathrm{m}} /\left(\mathrm{kJ} \cdot \mathrm{mol}^{-1}\right)$ \\
\hline 2.01 & 62.5 \\
3.25 & 62.5 \\
5.39 & 63.6 \\
8.94 & 63.3 \\
9.36 & 61.8 \\
11.40 & 61.5 \\
15.77 & 60.4 \\
& \\
& $62.2 \pm 1.0$ \\
\hline
\end{tabular}

This quantity was determined from the following standard thermodynamic equation:

$$
\begin{aligned}
\Delta_{\mathrm{l}}^{\mathrm{g}} H_{\mathrm{m}}^{\circ}(T=298.15 \mathrm{~K})= & \Delta_{\mathrm{cr}}^{\mathrm{g}} H_{\mathrm{m}}^{\circ}(T=298.15 \mathrm{~K})- \\
& \Delta_{\mathrm{cr}}^{1} H_{\mathrm{m}}(T=342.1 \mathrm{~K})- \\
& \int_{298.15}^{342.1}\left(C_{p, \mathrm{~m}}^{\mathrm{cr}}-C_{p, \mathrm{~m}}^{\mathrm{l}}\right) \mathrm{d} T,
\end{aligned}
$$

where $C_{p, \mathrm{~m}}^{\mathrm{cr}}$ and $C_{p, \mathrm{~m}}^{\mathrm{l}}$ are the solid and liquid isobaric heat capacities, respectively. The values obtained for $\Delta_{\mathrm{cr}}^{1} H_{\mathrm{m}}$, at $T=342.1 \mathrm{~K}$, for different masses of trans-cyclohexyl-1,4diamine are given in table 3 . The values derived for the temperature and enthalpy of fusion of this compound are presented in table 4 . The heat capacities were estimated as follows: $C_{p, \mathrm{~m}}^{\mathrm{cr}}$ was calculated by the method described in Rowley et al. [12] and the result found for this quantity is $C_{p, \mathrm{~m}}^{\mathrm{cr}} /\left(\mathrm{J} \cdot \mathrm{mol}^{-1} \cdot \mathrm{K}^{-1}\right)=1.617(T / \mathrm{K})^{0.793}$. The value taken for the heat capacity of the liquid was $C_{p, \mathrm{~m}}^{\mathrm{l}}=200.2 \mathrm{~J} \cdot \mathrm{mol}^{-1} \cdot \mathrm{K}^{-1}$, estimated by the method pro-

TABLE 3

Enthalpy of fusion values, $\Delta_{\mathrm{cr}}^{1} H_{\mathrm{m}}$, and fusion temperature, $T_{\text {fus }}$, obtained for different masses, $m$, of trans-cyclohexyl-1,4-diamine

\begin{tabular}{lll}
\hline$m / \mathrm{mg}$ & $T_{\text {fus }} / \mathrm{K}$ & $\Delta_{\mathrm{cr}}^{1} H_{\mathrm{m}} /\left(\mathrm{kJ} \cdot \mathrm{mol}^{-1}\right)$ \\
\hline 2.08 & 341.9 & 27.0 \\
3.67 & 342.2 & 26.8 \\
2.49 & 342.0 & 27.0 \\
4.92 & 342.1 & 27.3 \\
4.05 & 342.2 & 27.0 \\
& & $27.0 \pm 0.2$ \\
\hline
\end{tabular}

TABLE 1

Enthalpy of sublimation values, $\Delta_{\mathrm{cr}}^{\mathrm{g}} H_{\mathrm{m}}$, at $T=298.15 \mathrm{~K}$, obtained for different masses, $m$, of trans-cyclohexyl-1,4-diamine

\begin{tabular}{ll}
\hline$m / \mathrm{mg}$ & $\Delta_{\mathrm{cr}}^{\mathrm{g}} H_{\mathrm{m}} /\left(\mathrm{kJ} \cdot \mathrm{mol}^{-1}\right)$ \\
\hline 1.47 & 104.5 \\
2.27 & 106.3 \\
3.35 & 104.6 \\
3.92 & 105.8 \\
4.37 & 103.9 \\
4.48 & 105.0 \\
& \\
& $105.0 \pm 0.8$ \\
\hline
\end{tabular}

TABLE 4

Molar enthalpies of sublimation, $\Delta_{\mathrm{cr}}^{\mathrm{g}} H_{\mathrm{m}}^{\circ}$, and vaporization, $\Delta_{\mathrm{l}}^{\mathrm{g}} H_{\mathrm{m}}^{\circ}$, at $T=298.15 \mathrm{~K}$ and molar enthalpy of fusion, $\Delta_{\mathrm{cr}}^{1} H_{\mathrm{m}}$, of trans-cyclohexyl1,4-diamine at $T=342.1 \mathrm{~K}$ and molar enthalpy of vaporization of ciscyclohexyl-1,2-diamine at $T=298.15 \mathrm{~K}$

\begin{tabular}{lccc}
\hline$T_{\text {fus }} / \mathrm{K}$ & $\Delta_{\mathrm{cr}}^{1} H_{\mathrm{m}} /\left(\mathrm{kJ} \cdot \mathrm{mol}^{-1}\right)^{1} \Delta_{\mathrm{cr}}^{\mathrm{g}} H_{\mathrm{m}}^{\circ} /\left(\mathrm{kJ} \cdot \mathrm{mol}^{-1}\right)$ & $\Delta_{1}^{\mathrm{g}} H_{\mathrm{m}}^{\circ} /\left(\mathrm{kJ} \cdot \mathrm{mol}^{-1}\right)$ \\
\hline \multicolumn{4}{c}{ trans-Cyclohexyl-1,4-diamine } \\
$342.1 \pm 0.127 .0 \pm 0.2 \quad 105.0 \pm 0.8$ \\
\multicolumn{4}{c}{ cis-Cyclohexyl-1,2-diamine } \\
\multicolumn{4}{c}{$62.9 \pm 0.9$} \\
\hline
\end{tabular}


posed by Zábranský and Rủžička Jr. [13]. The value determined for the enthalpy of vaporization of trans-cyclohexyl1,4-diamine, at $T=298.15 \mathrm{~K}$, is presented in table 4 .

\section{Discussion}

The values obtained for the enthalpies of vaporization of the diamines studied are higher than those expected from cyclohexane and cyclohexylamine values. In fact, introducing an amine group into cyclohexane causes an increase in the enthalpy of vaporization of $9.78 \mathrm{~kJ} \cdot \mathrm{mol}^{-1}$ $\left(\Delta_{\mathrm{l}}^{\mathrm{g}} H_{\mathrm{m}}^{\circ}\right.$ of cyclohexane $=33.04 \mathrm{~kJ} \cdot \mathrm{mol}^{-1}[14]$ and $\Delta_{1}^{\mathrm{g}} H_{\mathrm{m}}^{\circ}$ of cyclohexylamine $\left.=(42.82 \pm 0.09) \mathrm{kJ} \cdot \mathrm{mol}^{-1}[15]\right)$. Given this, the further introduction of one amine group would lead to a value of the enthalpy of vaporization close to $52.6 \mathrm{~kJ} \cdot \mathrm{mol}^{-1}$. The experimental value of the enthalpy of vaporization of both diamines studied here is larger. This means that an increase in the enthalpy of the amines in the gas state or a decrease of this property in the liquid state occurs in relation to the values expected for cyclohexane and cyclohexylamine.

The enthalpy of the solid or liquid phase can be estimated from the enthalpy of sublimation/vaporization and the enthalpy of the compound in gas phase. The authors calculated the enthalpy of these diamines in the gas phase in earlier work $[8,10]$. They found that the enthalpy of trans-cyclohexyl-1,4-diamine is $6 \mathrm{~kJ} \cdot \mathrm{mol}^{-1}$ lower than that of the cis-isomer. The enthalpy of vaporization of the transisomer determined in the present work is $18 \mathrm{~kJ} \cdot \mathrm{mol}^{-1}$ higher than that of the cis-isomer. Thus the enthalpy of liquid trans-cyclohexyl-1,4-diamine is $24 \mathrm{~kJ} \cdot \mathrm{mol}^{-1}$ lower than that of liquid cis-cyclohexyl-1,2-diamine. Admitting that intermolecular forces are the main contribution to this difference, the hydrogen bonds between the $\mathrm{NH}_{2}$ groups, the main intermolecular bonds in liquid amines [16], are more favorable in the former isomer than in the second one.

In previous work on the molecular structure of cis-cyclohexyl-1,2-diamine [8], it was shown that the 1,2 position of the amine groups do not favor the geometric parameters for intramolecular hydrogen bond. This was also confirmed by natural bond orbital calculations [9]. The differences between the enthalpies of both diamine isomers in the gas state were interpreted as being due to repulsive interactions involving the $\mathrm{NH}_{2}$ groups. In trans-cyclohexyl-1,4diamine, the main repulsions occur between $\mathrm{NH}_{2}$ and the $\mathrm{C}-\mathrm{H}$ group to which the amine group is attached. The amine group's proximity in cis-cyclohexyl-1,2-diamine means that, besides the destabilizing factor observed in the 1,4-isomer, a significant repulsion between both $\mathrm{NH}_{2}$ groups takes place.

\section{Conclusions}

Data for the standard enthalpy of sublimation and vaporization of trans-cyclohexyl-1,4-diamine and the enthalpy of vaporization of cis-cyclohexyl-1,2-diamine are given for the first time in this paper.

The difference of the enthalpies of the isomers in the liquid state was calculated from the difference in the values found for the enthalpy of vaporization and those published for the enthalpy of both isomers in the gas state.

\section{Acknowledgment}

Luciana I.N. Tomé acknowledges Fundação para a Ciência e a Tecnologia (FCT), Lisbon, for financial support, Grant SFRH/BD/12373/2003.

\section{References}

[1] K.P.C. Vollhardt, N.E. Schore, Organic Chemistry: Structure and Function, fourth ed., W.H. Freeman, New York, 2002.

[2] Available at http://chemicalland21.com (accessed on 30.03.2007).

[3] Y.L. Bennani, S. Hanessian, Chem. Rev. 97 (1997) 3161-3195.

[4] G.D. Whitener, J.R. Hagadorn, J. Arnold, J. Chem. Soc., Dalton Trans. (1999) 1249-1255.

[5] J.A. Gavin, N. Deng, M. Alcalá, T.E. Mallouk, Chem. Mater. 10 (1998) 1937-1944.

[6] J. Balsells, L. Mejorado, M. Phillips, F. Ortega, G. Aguirre, R. Somanathan, P.J. Walsh, Tetrahedron: Asymmetry 9 (1998) 41354142 .

[7] A. Loussouarn, A. Ouadi, L. Morandeau, P. Remaud, R. Giles, J.F. Gestin, J. Webb, Tetrahedron Lett. 44 (2003) 3539-3541.

[8] L.I.N. Tomé, M.T.S. Rosado, M.E.S. Eusébio, J.S. Redinha, J. Mol. Struct. (THEOCHEM.) 804 (2007) 65-74.

[9] L.I.N. Tomé, M.T.S. Rosado, M.E.S. Eusébio, J.S. Redinha (in preparation).

[10] M.E.S. Eusébio, A.J.L. Jesus, M.S.C. Cruz, M.L.P. Leitão, J.S Redinha, J. Chem. Thermodyn. 35 (2003) 123-129.

[11] S.C.C. Nunes, M.E.S. Eusébio, M.L.P. Leitão, J.S. Redinha, Int. J. Pharm. 285 (2004) 13-21.

[12] B.T. Goodman, W.V. Wilding, J.L. Oscarson, R.L. Rowley, J. Chem. Eng. Data 49 (2004) 24-31.

[13] M. Zábranský, V. Růžička Jr., J. Phys. Chem. Ref. Data 33 (2004) 1071-1081.

[14] J.A. Riddick, W.B. Bunger, Organic Solvents, Wiley-Interscience, New York, 1970.

[15] S. Bergstrom, G. Olofsson, J. Solution Chem. 4 (1975) 535-555.

[16] S.W. Benson, J. Am. Chem. Soc. 118 (1996) 10645-10649.

JCT $07-154$ 